Egyptian Journal of Rabbit Science, 27 (1): 23-41(2017)

\title{
PRODUCTIVE PERFORMANCE, BLOOD CONSTITUENTS AND SOME PHYSIOLOGICAL PARAMETERS OF RABBIT BUCKS ADMINISTERED WITH BEE POLLEN UNDER HOT CONDITIONS PREVALENT IN ASSIUT
}

\author{
A. A. Abuoghaba ${ }^{1} ;$ H. Y. El-Hammady ${ }^{2}$ and M. G. Abd El-Fattah ${ }^{2}$ \\ 1 Department of Poultry Production, Faculty of Agriculture, Sohag \\ University, Sohag, Egypt. 82524. \\ 2 Department of Poultry Production, Faculty of Agriculture, Assiut \\ University, Assiut, Egypt. 71515. \\ "Corresponding Author: E-mail: Abuoghaba@yahoo.com
}

The impact of treatment with bee pollen $(\mathrm{BP})$ on the productive performance and some hematological and physiological traits of rabbit bucks were studied under hot climatic conditions prevalent in Assiut during the summer season. A number of 30 rabbit bucks (15 Vline \& 15 Moshtohor line); 14 weeks old were divided into three equal experimental groups. The bucks of $1^{\text {st }}$ group were fed on a commercial basal ration and served as control, while those in the $2^{\text {nd }}$ and $3^{\text {rd }}$ groups were fed on the same ration in addition to daily oral supplementation with 250 and $500 \mathrm{mg}$ BP/buck, respectively in gelatin capsulated form allover experimental period.

The obtained results revealed significant rabbit line differences in total feed intake (TFI/g), RBCs $\left(10^{6}\right)$, total protein (TP), glucose ( $\mathrm{mg} / \mathrm{dl})$, total lipids $(\mathrm{g} / \mathrm{L})$, aminotransferase (ALT/IU/L), IgG $(\mathrm{mg} / \mathrm{dl})$, IgM ( $\mathrm{mg} / \mathrm{dl})$ and Tri-iodothyronine (T3/ng/dl) hormone concentration. While, the differences were insignificant in the productive traits, $\mathrm{Hb}$ $(\mathrm{g} / \mathrm{dl}), \mathrm{HTC}(\%)$, cholesterol $(\mathrm{g} / \mathrm{dl})$, total antioxidant capacity $(T A C / \mathrm{mm} / \mathrm{l})$, aspartate aminotransferase (AST), follicle-stimulating hormone (FSH), testosterone (Testos) and Luteinizing hormone (LH) hormone concentrations. The total feed intake of bucks treated with 250 and 500mg BP/buck decreased by 4.45 and $8.48 \%$, but the means of $B W(g), B W G(g)$ and PI $(\%)$ increased significantly $(P<0.01$ or $0.05)$ than those of the control. The means of $\mathrm{Hb}(\mathrm{g} / \mathrm{dl}), \mathrm{HTC}(\%)$, RBCs $\left(10^{6}\right)$ and Lymphocytes (\%) of the bucks treated with BP increased significantly $(P<0.01$ or 0.05$)$ than those of the control. The means of TP, albumin, globulin $(\mathrm{g} / \mathrm{dl})$ and glucose $(\mathrm{mg} / \mathrm{dl})$ levels as well as TAC (\%), IgG ( $\mathrm{mg} / \mathrm{dl}), \operatorname{IgM}(\mathrm{mg} / \mathrm{dl})$ of the treated bucks significantly $(P<0.01$ or 0.05$)$ increased, whereas the levels of 
cholesterol (mg/dl), total lipids (TL/g/l), AST (IU/l) and ALT (IU/l) were significantly $(P<0.01$ or 0.05$)$ decreased. In the treated bucks, the concentrations of testosterone, FSH, and LH hormones improved significantly $(P<0.01)$ than those of the control group.

Conclusively, it could be concluded that treating rabbits raised under hot climatic conditions with 250 and $500 \mathrm{BP} /$ buck improved significantly the feed intake, hematological variables, immunological responses and hormonal estimates.

Keywords: Bee Pollen, Rabbit bucks, Performance, Immunological parameters, Physiological measurements.

The use of antibiotics in animal and poultry production was banned by the European community in 2006. Therefore, several studies were performed to find out other alternative biological products to improve the efficiency of feed utilization of rabbits, which consequently results in higher growth rate, better immunity and more efficient financial profitability (Perić et al., 2009 and Dias et al., 2013). Bee pollen is an agglomerate of flower pollen grains, gathered by honey bees and mixed with plant nectar and bee saliva enzymes, which improves its therapeutical efficiency (Carpes et al., 2008 and Leblanc et al., 2009). Bee pollen is a rich source of protein (25-30\%), polyunsaturated fatty acids $(51 \%)$ as well as linolenic acid $39 \%$, palmitic acid $20 \%$, and linoleic acid $13 \%$ and more than 12 vitamins, 28 minerals as $\mathrm{Zn}, \mathrm{Cu}, \mathrm{Fe}, \mathrm{Se}$ and high $\mathrm{K} / \mathrm{Na}$ ratio, 59 trace elements, 11 enzymes or coenzymes, 35-65\% carbohydrates, which include glucose, fructose and sucrose in addition to flavonoids, carotenoids and phytosterols ( $\mathrm{Xu}$ et al., 2009; Attia et al., 2011a, b and Hašćík, et al., 2012).

The chemical analysis of bee pollen, as found by many researchers is rich in provitamins and vitamins: thiamine, riboflavin, pyridoxine, nicotinic acid, pantothenic acid, folic acid, beta-carotene, vitamin $\mathrm{C}$, tocopherol and ergocalciferol (Villanueva, 2002 and Bastos, 2004), and in minerals as phosphorus, potassium, iron, magnesium, copper, zinc and manganese (Human and Nicolson, 2003). Similarly, Carpes et al., (2007) and Campos et al., (2010) stated that the bee pollen is rich in polyphenolic substances, flavonoids, phytosterols and other health-promoting substances, which indicate the presence of free radical scavenging and antioxidants activity. Also, the findings of some researchers revealed that bee pollen tended to have some therapeutical characteristics as antibacterial (Proestos et al. 2005), antifungal (García et al., 2001), antibiotic, antidiarrhoeic and antioxidant (Almaraz-Abarca et al. 2004 and Hajkova et al. 2013). Besides, 
Song et al. (2005) stated that BP could improve the cell immune response through enhancing the speed of antibody production and reinforcing the immunological system.

Also, the findings of Attia et al. (2011a and 2014) indicated that the BWG of newly weaned kids treated with BP increased significantly and coincided with improve feed conversion ratio up to 12 weeks of age, while the feed consumption and the mortality rate were relatively decreased. Similarly, the results of El-Hanoun et al. (2007) indicated that treating the growing rabbits with 250 and $500 \mathrm{mg}$ bee pollen/kg BW increased significantly their growth and survival rate from weaning up to mature age. Also, Hedia et al. (2007) reported that treating rabbits with BP increased the plasma glucose, total protein, and albumin concentrations.

Therefore, the current study aimed to evaluate the impact of supplementing rabbit bucks with BP on the productive performance, liver enzymes and some physiological and immunological traits.

\section{MATERIALS AND METHODS}

The present study was performed at the Experimental Rabbitry Farm of Poultry Production Department, Faculty of Agriculture, Assiut University during the period from June up to September, 2015. It worth to mention that the local Egyptian Moshtohor line was developed by crossing Spanish V-line rabbit does with Sinai Gabali bucks (Iraqi et al., 2008). The Spanish V-line is a synthetic maternal line, which originated at the Department of Animal Science, Universitat Politecnica de Valencia, Spain in 1983 by crossing the progeny of four specialized maternal lines without selection for three generations and has been selected for weaned litter size (Estany et al., 1989).

\section{Experimental animals and management}

Thirty healthy rabbit bucks including 15 of both V-line and Moshtohor line; 14 weeks old were divided into three equal groups. Bucks in the $1^{\text {st }}$ group (control) were fed on a the commercial basal ration, while those in the $2^{\text {nd }}$ and $3^{\text {rd }}$ groups were fed the same ration but administered orally daily with 250 and $500 \mathrm{mg} \mathrm{BP} / \mathrm{buck}$ in capsulated form and considered as treated groups. All bucks were individually placed in wire galvanized battery cages $(50 \mathrm{~L} \times 50 \mathrm{~W} \times 40 \mathrm{H})$ under the same adequate environmental conditions, and exposed to 16 lighting hours/ daily. The fed and fresh tap water was provided ad-libitum. 
The commercial basal ration included $17.0 \%$ crude protein, $2.99 \%$ fat, $12.5 \%$ crude fiber, $0.6 \%$ minerals mixture and $2500 \mathrm{~K} \mathrm{cal} / \mathrm{kg}$ digestible energy, which covered the needed requirements according to A.O.A.C., (2000).

\section{Environmental conditions}

Ambient temperature $\left({ }^{\circ} \mathrm{C}\right)$ and relative humidity $(\%)$ were recorded inside the rabbitry allover the day by using a thermo-hygrograph. The averages of minimal and maximal ambient temperature as well as the relative humidity were measured as shown in Table 1.

The maximal temperature was determined as the average of five measurements at 10AM, 12Noon, 2, 4 and $6 \mathrm{PM}$, while the minimal temperature was determined at 8 and $10 \mathrm{PM}, 12 \mathrm{Mid}$ night, 2 and 4AM, respectively. The temperature humidity indices (THI) were calculated according to the equation of Marai et al., 2001:

$\mathrm{THI}=\mathrm{db}^{\circ} \mathrm{C}-\left[(0.31-0.31 \times \mathrm{RH}) \times\left(\mathrm{db}^{\circ} \mathrm{C}-14.4\right)\right]$,

Where $\mathrm{db}^{\circ} \mathrm{C}=$ Dry bulb temperature and $\mathrm{RH} \%=$ Relative humidity. The values of THI were classified into four categories: <27.8 (absence of heat stress), 27.8-28.8 (Moderate heat stress), 28.9-29.9 (Severe heat stress) and $>30.0$ (Very severe heat stress).

Table 1. Ambient temparature $\left(\mathrm{ATl}^{\circ} \mathrm{C}\right)$, Relative humidity $(\mathrm{RH} / \%)$ and THI (units) allover the experimental period

\begin{tabular}{|c|c|c|c|c|c|c|c|c|c|}
\hline \multirow{2}{*}{ Months } & \multicolumn{3}{|c|}{ Minimum } & \multicolumn{3}{c|}{ Maximum } & \multicolumn{3}{c|}{ Mean } \\
\cline { 2 - 9 } & $\begin{array}{c}\text { AT } \\
\left({ }^{\circ} \mathbf{C}\right)\end{array}$ & $\begin{array}{c}\text { RH } \\
(\boldsymbol{\%})\end{array}$ & $\begin{array}{c}\text { THI } \\
(\mathbf{U n i t s})\end{array}$ & $\begin{array}{c}\text { AT } \\
\left({ }^{\circ} \mathbf{C}\right)\end{array}$ & $\begin{array}{c}\text { RH } \\
(\boldsymbol{\%})\end{array}$ & $\begin{array}{c}\text { THI } \\
(\mathbf{U n i t s})\end{array}$ & $\begin{array}{c}\text { AT } \\
\left({ }^{\circ} \mathbf{C}\right)\end{array}$ & $\begin{array}{c}\text { RH } \\
(\boldsymbol{\%})\end{array}$ & $\begin{array}{c}\text { THI } \\
(\text { Units })\end{array}$ \\
\hline June & 26.4 & 58 & 24.84 & 38 & 48 & 34.19 & 32.2 & 53 & 29.60 \\
\hline July & 28.4 & 55 & 26.45 & 41 & 52 & 37.04 & 34.7 & 53.5 & 31.77 \\
\hline Aug & 28.2 & 52 & 26.12 & 42 & 48 & 37.55 & 35.1 & 50 & 31.89 \\
\hline Sep & 26.6 & 58 & 25.01 & 40 & 52 & 36.19 & 33.3 & 55 & 30.66 \\
\hline
\end{tabular}

AT $\left({ }^{\circ} \mathrm{C}\right)=$ Ambient temperature, RH $(\%)=$ Relative humidity, THI (units) $=$

Temperature humidity index

\section{Traits under study:}

Productive performance: The initial and final body weights for each buck were recorded at $9.0 \mathrm{AM}$ o'clock in the $14^{\text {th }}$ and $24^{\text {th }}$ weeks of the experimental period. The total BWG was calculated during the period between 14 and 24 weeks of age by subtracting the initial body weight from the final corresponding ones. The total feed consumption (g) was recorded during the same period. The feed conversion ratio (FCR) was calculated as $\mathrm{g}$ feed/g weight gain. The performance index (PI) was calculated as (Final body weight $(\mathrm{kg}) /$ Feed conversion $) \times 100\}$ according to North $(1981)$. 
Blood parameters: At $22^{\text {nd }}$ weeks of age (after 8 weeks from the beginning of experiment), 30 blood samples, 10 samples in each group (3 $\mathrm{ml}$ each) were collected at 10.0 AM from the marginal ear vein in both heparinized and nonheparinized tubes to measure biochemical analysis.

Hematological parameters: All blood samples were run in duplicate and assayed by the same investigator, who was blind to the experimental situation. Non-coagulated blood was tested shortly after collection for the count of red blood cells (RBCs, $10^{6}$ ), white blood cells (WBCs, $10^{3}$ ), Differential count of WBC's subclasses (lymphocyte, neutrophils, monocytes, eosinophils, and basophils percentages), hemoglobin $(\mathrm{Hb}, \mathrm{g} / \mathrm{dl})$ concentration and hematocrit value (HTC, \%) according to Drew et al. (2004).

Therefore, blood samples were separated by centrifugation at 3000 rpm for 15 minutes and kept in a deep freezer at $\left(-20^{\circ} \mathrm{C}\right)$ until analysis.

Blood constituents: The serum total protein (TP) was measured by using commercial kits according to the method of Armstrong and Corri (1960), while serum albumin (Alb) was determined by using special kits according to Doumas et al. (1971). Globulin values were obtained by subtracting albumin concentrations from the corresponding values of the total protein. Total lipids and cholesterol levels in the serum were measured by using specialized commercial kits (Diamond Diagnostic, Egypt). Plasma total antioxidant capacity (mmol/L) was measured according to Erel (2004).

Liver enzymes: The plasma Aspartate aminotransferase (AST) and Alanine aminotransferase (ALT) were assayed according to Reitman and Frankel (1957).

Hormonal estimates: The concentrations of serum follicle stimulating hormone (FSH/ ng/ml), and Luteinizing hormone ( $\mathrm{LH} / \mathrm{MIU} / \mathrm{ml}$ ) hormone were determined by ELISA technique, while plasma testosterone $(\mathrm{ng} / \mathrm{ml})$ and tri-iodothyronine (T3) hormones were measured by DRG International, Inc., USA Kits According to the method of Tietz, (1995).

Statistical analysis: Data were analyzed by the least square analysis of variance using GLM procedure of the statistical analysis model (SAS, 2004) as follow:

$$
Y i j=\mu+B_{i}+T_{j}+B_{i} T_{j}+e_{i j}
$$

Where: $Y_{i j}=$ The individual observation, $\mu=$ Overall mean, $B_{i}=$ Rabbit line $(\mathrm{i}=1,2), \mathrm{Tj}=$ Effect of $\mathrm{BP}$ treatment $(\mathrm{j}=1,2$ and 3$), \mathrm{BT}_{\mathrm{ij}}=$ Fixed interacting effect between rabbit line and $\mathrm{BP}$ treatment; Eij= Random error component was normally distributed assumed.

The significant differences between treatment means were determined by using Duncan's new multiple ranges tests (Duncan, 1955). 


\section{RESULTS AND DISCUSSIONS}

Data presented in Table 2, showed significant $(\mathrm{P}<0.004)$ differences in total feed intake between $\mathrm{V}$-line and Moshtohor lines, while those of BW, BWG, FCR and PI were insignificantly affected. The improved feed intake for V-line bucks may be due to genetical differences. These results disagree with those of El-Bayomi et al., (2012), who found that the progeny of different genotypes varied significantly in weights at weaning and postweaning.

Regarding the treatment of $\mathrm{BP}$, the achieved results revealed that the FBW (g), BWG (g) and PI (\%) for bucks in the treated groups were significantly $(\mathrm{P}<0.01)$ increased than those of the control. In contrast, TFI $(\mathrm{g})$ and FCR for the treated bucks were significantly $(\mathrm{P}<0.001)$ improved by about $(4.4 \& 8.5 \%)$ and $(18.2 \& 22.4 \%)$ than those of control. The increased FBW, BWG and PI in the treated groups could be attributed to improved digestibility of the crude protein, which in turn improved the nutrient and protein utilization resulting in higher protein anabolism and intestinal absorptive capacity.

The decreased total feed intake of the treated bucks may be due to the role of BP in improving the protein utilization by the flavonoids, which consequently enhanced the digestion, absorption, and utilization of nutrients. The obtained results are in agreement with those of El-Hanoun et al. (2007), who stated that the orally administered NZW rabbit does with 100,200 , and $300 \mathrm{mg}$ propolis $/ \mathrm{kg}$, BW and feed conversion ratio were significantly improved, while the averages of daily feed consumption were significantly inferior to those in control group. Also, the achieved findings agree with those of Attia et al. (2011a), who found that the feed intake of kids produced by rabbit does supplemented with bee pollen decreased remarkably than those of the control group from 4 to 12 weeks of age. Similarly, Abou El-Naga (2014) found that the feed intake of Norfa chicken administrated with 1 or $2 \%$ BP decreased significantly $(\mathrm{P} \leq 0.05)$, which improved the FCR than those of the control. The interactions between lines and BP treatments were insignificant in all productive studied traits except the total feed intake. There were no mortality cases during the experimental period, which lasted 10 weeks.

\section{Hematological variables}

The obtained results in Table 3 indicate significant $(\mathrm{P} \leq 0.01$ or 0.05$)$ line differences in RBCs $\left(10^{6}\right)$, Lymphocytes and Neutrophils. In contrast, the means of $\mathrm{Hb}$, HTC, WBCS $\left(10^{3}\right)$, monocytes, eosinophils and basophils 
Table 2. Productive performance of rabbit bucks affected by lines, BP treatment and their interaction

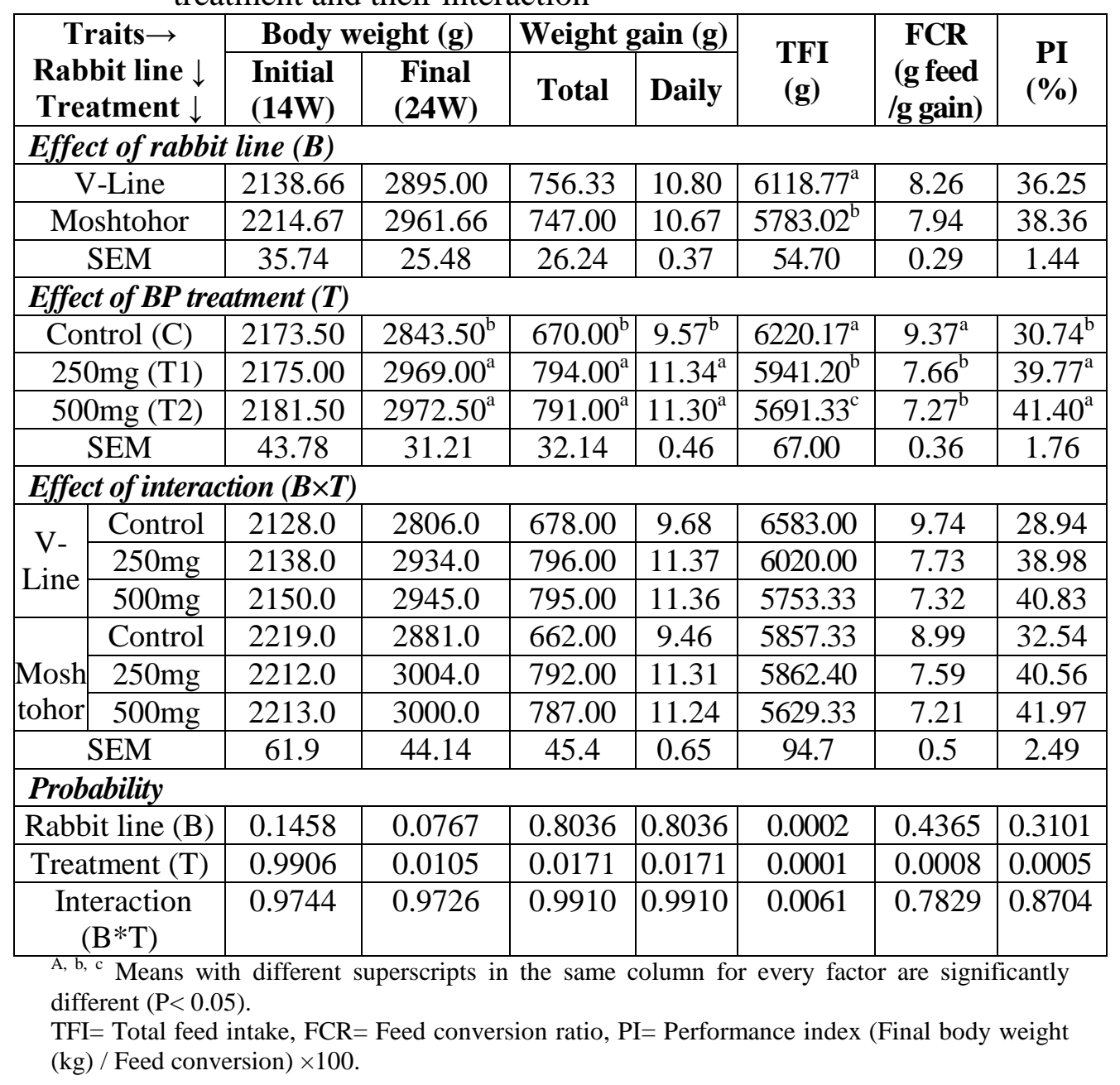

were insignificantly affected. The Moshtohor rabbit bucks showed significant higher RBCs $\left(10^{6}\right)$ and Neutrophils (\%) than their corresponding in V-line rabbit bucks. This might be attributed to the improved hepatic functions of Moshtohor than those of V-line bucks. These results agree with those of Khalil et al., (2015), who found that the means of RBCs, Neutrophils, lymphocytes for Baladi bucks increased significantly $(\mathrm{P}<0.01)$, while the means of $\mathrm{Hb}, \mathrm{PCV}$ and Monocytes were insignificantly affected as compared with the corresponding values of NZW rabbit bucks.

Referring to the treatment with $\mathrm{BP}$, the achieved findings indicated that the means of $\mathrm{Hb}(\mathrm{g} / \mathrm{dl}), \mathrm{HTC}(\%)$, RBCs $\left(10^{6}\right)$, Lymphocytes and 
Table 3. Hematological variables of rabbit bucks affected by rabbit lines, $\mathrm{BP}$ treatment and their interaction

\begin{tabular}{|c|c|c|c|c|c|c|c|c|c|c|}
\hline \multirow{2}{*}{\multicolumn{2}{|c|}{$\begin{array}{c}\text { Traits } \rightarrow \\
\text { Rabbit line } \downarrow \\
\text { Treatment } \downarrow\end{array}$}} & \multirow[b]{2}{*}{$\underset{(\mathbf{g} / \mathbf{d l})}{\mathbf{H g}}$} & \multirow[b]{2}{*}{$\begin{array}{c}\text { HTC } \\
(\%)\end{array}$} & \multirow[b]{2}{*}{$\begin{array}{c}\text { RBCs } \\
\left(10^{6}\right)\end{array}$} & \multirow{2}{*}{$\begin{array}{c}\text { WBCS } \\
\left(10^{3}\right)\end{array}$} & \multicolumn{5}{|c|}{ WBCS deferential } \\
\hline & & & & & & $\begin{array}{c}\mathrm{L} \\
(\%)\end{array}$ & $\begin{array}{c}\text { M } \\
(\%)\end{array}$ & $\begin{array}{c}\mathbf{N} \\
(\%)\end{array}$ & $\begin{array}{c}\mathbf{E} \\
(\%)\end{array}$ & $\begin{array}{r}\text { B } \\
(\%)\end{array}$ \\
\hline \multicolumn{11}{|c|}{ Effect of rabbit line $(B)$} \\
\hline \multicolumn{2}{|c|}{ V-Line } & 11.26 & 31.16 & $5.32^{\mathrm{b}}$ & 6.46 & $64.13^{\mathrm{a}}$ & 1.74 & $30.99^{\mathrm{b}}$ & 1.64 & 1.51 \\
\hline \multicolumn{2}{|c|}{ Moshtohor } & 11.97 & 32.12 & $5.71^{\mathrm{a}}$ & 6.68 & $62.91^{\mathrm{b}}$ & 1.66 & $32.47^{\mathrm{a}}$ & 1.58 & 1.37 \\
\hline \multicolumn{2}{|c|}{ SEM } & 0.36 & 0.41 & 0.07 & 0.18 & 0.25 & 0.08 & 0.22 & 0.08 & 0.05 \\
\hline \multicolumn{11}{|c|}{ Effect of BP treatment $(T)$} \\
\hline \multicolumn{2}{|c|}{ Control (C) } & $10.48^{\mathrm{b}}$ & $29.24^{\mathrm{c}}$ & $5.24^{b}$ & 6.29 & $60.42^{\mathrm{c}}$ & $1.92^{\mathrm{a}}$ & $34.33^{\mathrm{a}}$ & 1.73 & $1.60^{\mathrm{a}}$ \\
\hline \multicolumn{2}{|c|}{$250 \mathrm{mg}(\mathrm{T} 1)$} & $11.90^{\mathrm{a}}$ & $31.48^{\mathrm{b}}$ & $5.53^{\mathrm{a}}$ & 6.61 & $64.03^{\mathrm{b}}$ & $1.73^{\mathrm{ab}}$ & $31.19^{\mathrm{b}}$ & 1.64 & $1.41^{\mathrm{b}}$ \\
\hline \multicolumn{2}{|c|}{$500 \mathrm{mg}(\mathrm{T} 2)$} & $12.46^{\mathrm{a}}$ & $34.18^{\mathrm{a}}$ & $5.77^{\mathrm{a}}$ & 6.81 & $66.11^{\mathrm{a}}$ & $1.46^{\mathrm{b}}$ & $29.67^{\mathrm{c}}$ & 1.46 & $1.30^{\mathrm{b}}$ \\
\hline \multicolumn{2}{|c|}{ SEM } & 0.44 & 0.50 & 0.08 & 0.22 & 0.30 & 0.10 & 0.27 & 0.096 & 0.06 \\
\hline \multicolumn{11}{|c|}{ Interaction $(B \times T)$} \\
\hline \multirow{3}{*}{ V-Line } & Control & 10.90 & 30.13 & 5.36 & 6.46 & 60.52 & 1.96 & 34.08 & 1.80 & 1.64 \\
\hline & $250 \mathrm{mg}$ & 12.04 & 32.16 & 5.68 & 6.38 & 64.92 & 1.74 & 30.24 & 1.64 & 1.46 \\
\hline & \begin{tabular}{|l|}
$500 \mathrm{mg}$ \\
\end{tabular} & 12.98 & 34.06 & 6.08 & 6.54 & 66.94 & 1.52 & 28.64 & 1.48 & 1.42 \\
\hline \multirow{3}{*}{$\begin{array}{c}\text { Moshto- } \\
\text { hor }\end{array}$} & Control & 10.06 & 28.36 & 5.12 & 6.12 & 60.32 & 1.88 & 34.58 & 1.66 & 1.56 \\
\hline & $250 \mathrm{mg}$ & 11.76 & 30.82 & 5.38 & 6.84 & 63.13 & 1.72 & 32.14 & 1.64 & 1.37 \\
\hline & \begin{tabular}{|l|}
$500 \mathrm{mg}$ \\
\end{tabular} & 11.94 & 34.30 & 5.46 & 7.08 & 65.27 & 1.39 & 30.70 & 1.44 & 1.19 \\
\hline \multicolumn{2}{|c|}{ SEM } & 0.62 & 0.70 & 0.12 & 0.31 & 0.42 & 0.14 & 0.38 & 0.14 & 0.09 \\
\hline \multicolumn{11}{|c|}{ Probability } \\
\hline \multicolumn{2}{|c|}{ Rabbit line (B) } & 0.1730 & 0.1095 & 0.0005 & 0.3903 & \begin{tabular}{|l|}
0.0018 \\
\end{tabular} & 0.5091 & \begin{tabular}{|l|}
0.0001 \\
\end{tabular} & 0.5880 & 0.0793 \\
\hline \multicolumn{2}{|c|}{ Treatment $(\mathrm{T})$} & 0.0124 & 0.0001 & 0.0007 & 0.2530 & 0.0001 & 0.0123 & 0.0001 & 0.1581 & 0.0092 \\
\hline \multicolumn{2}{|c|}{ Interaction $(\mathrm{B} \times \mathrm{T})$} & 0.8178 & 0.3410 & 0.2454 & 0.2976 & \begin{tabular}{|l|l|}
0.1344 \\
\end{tabular} & 0.9381 & 0.1046 & 0.8635 & 0.6393 \\
\hline
\end{tabular}

Neutrophils $(\%)$ in the treated bucks increased significantly $(\mathrm{P} \leq 0.01$ or 0.05$)$, while the means of Monocytes and Basophils were significantly $(\mathrm{P} \leq 0.01)$ decreased than the corresponding levels of the control.

The increased $\mathrm{Hb}(\mathrm{g} / \mathrm{dl})$, HTC $(\%)$ and RBCs $\left(10^{6}\right)$ as well as Lymphocytes and Neutrophils percentages for treated bucks may be due to the stimulating role of bee pollen in enhancing the immune functions through increasing $\mathrm{Hb}(\mathrm{g} / \mathrm{dl})$, HTC $(\%)$ and RBCs $\left(10^{6}\right)$. This means that the addition of bee pollen increased RBC's, which consequently rose both of the hematocrit and hemoglobin levels.

In mammals, the lymphocyte is considered as a good indicator for increasing the immune responses in addition to a considerable increase in the main type of WBC's counts. Song et al., (2005) found that supplementing the 
rations of rabbits with $\mathrm{BP}$ could improve the cellular immune responses through enhancing the speed of antibody production and immunological system. The achieved findings agree with those of Ondruska et al., (2011), who stated that exposing NZW rabbits to heat stress decreased the level of ACTH, which resulted in decreasing the $\mathrm{Hb}$ concentration and RBC counts. Similar results were also obtained by El-Neney and El-Kholy (2014), who stated that the RBC's, and WBC's counts in rabbits treated with BP were significantly $(\mathrm{P} \leq 0.05)$ increased than those of the control. These findings showed that the interactions among rabbit line and treatments had no significant effects on the hematological traits.

\section{Blood constituents}

Data in Table 4 revealed that the differences in the concentrations of total protein for both rabbit lines were significantly affected, while the levels of albumin and globulin were not affected. The average of total protein $(\mathrm{mg} / \mathrm{dl})$ in Moshtohor bucks exceeded significantly than that of the V-line bucks. This improvement may be attributed to the more enlarged, vital and active liver of Moshtohor bucks than those of V-line. The achieved findings agree with those of Abdel-Hamid and Farahat (2015), who reported that the means of blood protein concentrations varied significant $(P<0.01)$ between the different breeds.

The achieved means of glucose $(\mathrm{g} / \mathrm{dl})$ and total lipids $(\mathrm{g} / \mathrm{L})$ in Moshtohor rabbit bucks increased significantly $(P<0.05)$ than those of the $\mathrm{V}$-Line bucks. These differences may be attributed to the genetically variations, which are of great diagnostic significance through the contribution in protein and the involvement of the enzymes, hormones and antibodies as well as in keeping the osmotic pressure, maintaining the acid-base balance, in addition being a nutritional reserve source for the body's tissues and muscles. The decreased glucose level in V-line kids may be due to the increased utilization of glucose resulting in increasing secretions of anabolic and catabolic enzymes, which consequently improve the metabolic rate. 
Regarding the effects of $\mathrm{BP}$, the achieved results indicated that the bucks treated with BP had the highest total protein $(\mathrm{P}<0.001)$, albumin $(\mathrm{P}<0.01)$ and globulin $(\mathrm{P}<0.001)$ than those of the control. The increased total proteins in the treated groups may be due to the improved digestibility of crude protein, which increases the amino acids supplementation. These results are in agreement with those of El- nagar et al., (2010), who found that the serum total protein in growing rabbits, which have been orally given once a week at 200,400 or $800 \mathrm{mg}$ royal jelly $(\mathrm{RJ}) / \mathrm{kg}$ BW significantly increased than those of the control. Similar results were also reported by Attia et al., (2014), who found that the means of albumin and globulin levels for growing rabbit were insignificantly affected by BP supplementation in the diet.

The obtained findings showed that the treated bucks with BP significantly $(\mathrm{P}<0.0001)$ increased the glucose $(\mathrm{g} / \mathrm{dl})$ level, while the means of the cholesterol $(\mathrm{mg} / \mathrm{dl})$ and total lipids $(\mathrm{g} / \mathrm{L})$ were significantly decreased $(\mathrm{P}<0.0001)$ than those of the control. The increased glucose levels for the treated bucks with BP could be attributed to increased sugar availability, especially for both biochemical and physiological body functions. The decreased cholesterol and total lipids for bucks treated with BP could be attributed to the impact of BP on lipid metabolism, in addition to the positive effects of the unsaturated fatty acids, which prevent the accumulation of lipid peroxidation products. The achieved findings agree with those of El-Neney and El-Kholy (2014), who stated that the glucose level increased significantly, while the means of cholesterol and total lipids for the male growing NZW rabbits, which were daily supplemented with 200, 300 and $400 \mathrm{mg} \mathrm{BP} / \mathrm{kg} \mathrm{BW}$, decreased significantly $(\mathrm{P}<0.05)$ than those of the control. The achieved results agree with those of $\mathrm{Xu}$ et al., (2009), who attributed the decreased levels of cholesterol and lipids to the impact of phospholipids and linolenic fatty acid in BP, which represented about $1.19 \%$.

The increased total antioxidant capacity $(\mathrm{TAC} / \mathrm{mm} / \mathrm{l})$ in the treated bucks may be attributed to the increase of absorbed vitamins, amino acids and trace elements from bee pollen, which consequently improved the proliferation, development, and differentiation of the intestinal cells resulting in improving the conditions of intestinal microbial activity. These results agree with the findings of Attia et al., (2014), which showed a significant 
Table 4. Blood constiuintes (within normal range) of rabbit bucks affected by rabbit line, BP treatment and their interaction

\begin{tabular}{|c|c|c|c|c|c|c|c|c|}
\hline \multirow{2}{*}{\multicolumn{2}{|c|}{$\begin{array}{c}\text { Traits } \rightarrow \\
\text { Rabbit line } \downarrow \\
\text { Treatment } \downarrow\end{array}$}} & \multicolumn{3}{|c|}{ Blood proteins } & \multirow[b]{2}{*}{$\begin{array}{c}\text { Glucose } \\
\text { (mg/dl) }\end{array}$} & \multirow[b]{2}{*}{$\begin{array}{c}\text { Cholesterol } \\
\text { (mg/dl) }\end{array}$} & \multirow{2}{*}{$\begin{array}{c}\text { Total } \\
\text { Lipids } \\
\text { (g/L) }\end{array}$} & \multirow[b]{2}{*}{$\begin{array}{c}\text { TAC } \\
(\mathbf{m m} / \mathbf{l})\end{array}$} \\
\hline & & $\begin{array}{c}\mathbf{T P} \\
(\mathrm{g} / \mathrm{dl})\end{array}$ & $\begin{array}{l}\text { Alb } \\
\text { (g/dl) }\end{array}$ & $\begin{array}{c}\text { Glob } \\
\text { (g/dl) }\end{array}$ & & & & \\
\hline \multicolumn{9}{|c|}{ Effect of rabbit line $(B)$} \\
\hline \multicolumn{2}{|c|}{ V-Line } & $7.75^{b}$ & 4.25 & 3.50 & $112.24^{\mathrm{b}}$ & 74.53 & $3.99^{b}$ & 0.79 \\
\hline \multicolumn{2}{|c|}{ Moshtohor } & $7.96^{\mathrm{a}}$ & 4.31 & 3.66 & $120.21^{\mathrm{a}}$ & 77.81 & $4.69^{\mathrm{a}}$ & 0.82 \\
\hline \multicolumn{2}{|c|}{ SEM } & 0.073 & 0.05 & 0.06 & 1.10 & 1.95 & 0.11 & 0.02 \\
\hline \multicolumn{9}{|c|}{ Effect of BP treatment $(T)$} \\
\hline \multicolumn{2}{|c|}{ Control (C) } & $7.24^{\mathrm{c}}$ & $4.19^{b}$ & $3.05^{\mathrm{c}}$ & $100.30^{c}$ & $90.25^{\mathrm{a}}$ & $4.87^{\mathrm{a}}$ & $0.58^{b}$ \\
\hline \multicolumn{2}{|c|}{$250 \mathrm{mg}(\mathrm{T} 1)$} & $7.94^{b}$ & $4.26^{\mathrm{ab}}$ & $3.68^{b}$ & $120.08^{b}$ & $71.20^{\mathrm{b}}$ & $4.21^{b}$ & $0.89^{\mathrm{a}}$ \\
\hline \multicolumn{2}{|c|}{$500 \mathrm{mg}(\mathrm{T} 2)$} & $8.40^{\mathrm{a}}$ & $4.39^{\mathrm{a}}$ & $4.01^{\mathrm{a}}$ & $128.31^{\mathrm{a}}$ & $67.06^{\mathrm{b}}$ & $3.93^{b}$ & $0.95^{\mathrm{a}}$ \\
\hline \multicolumn{2}{|c|}{ SEM } & 0.09 & 0.06 & 0.07 & 1.34 & 2.39 & 0.13 & 0.03 \\
\hline \multicolumn{9}{|c|}{ Interaction $(B \times T)$} \\
\hline \multirow{3}{*}{ V-Line } & Control & 7.11 & 4.16 & 2.95 & 98.30 & 86.00 & 4.61 & 0.56 \\
\hline & $250 \mathrm{mg}$ & 7.84 & 4.22 & 3.62 & 114.04 & 70.00 & 3.82 & 0.88 \\
\hline & $500 \mathrm{mg}$ & 8.30 & 4.36 & 3.94 & 124.40 & 67.60 & 3.55 & 0.93 \\
\hline \multirow{3}{*}{$\begin{array}{c}\text { Mosht- } \\
\text { ohor }\end{array}$} & Control & 7.37 & 4.22 & 3.15 & 102.30 & 94.50 & 5.16 & 0.60 \\
\hline & $250 \mathrm{mg}$ & 8.04 & 4.30 & 3.73 & 126.12 & 72.40 & 4.60 & 0.91 \\
\hline & $500 \mathrm{mg}$ & 8.50 & 4.42 & 4.08 & 132.22 & 66.52 & 4.32 & 0.96 \\
\hline \multicolumn{2}{|c|}{ SEM } & 0.13 & 0.09 & 0.11 & 1.90 & 3.38 & 0.19 & 0.04 \\
\hline \multicolumn{9}{|c|}{ Probability } \\
\hline \multicolumn{2}{|c|}{ Rabbit line (B) } & 0.0466 & 0.3805 & 0.0934 & 0.0001 & 0.2474 & 0.0002 & 0.3148 \\
\hline \multicolumn{2}{|c|}{ Treatment (T) } & 0.0001 & 0.0951 & 0.0001 & 0.0001 & 0.0001 & 0.0001 & 0.0001 \\
\hline \multicolumn{2}{|c|}{ Interaction $(\mathrm{B} \times \mathrm{T})$} & 0.9664 & 0.9864 & 0.9272 & 0.1272 & 0.3729 & 0.7897 & 0.9764 \\
\hline
\end{tabular}

$\mathrm{A}, \mathrm{b}, \mathrm{c}$ Means with different superscripts in the same column for every factor are significantly different $(\mathrm{P}<0.05) . \mathrm{TP}=$ Total protein, $\mathrm{Alb}=$ Albumin, $\mathrm{Glob}=$ globulin, $\mathrm{TAC}=$ Total antioxidant capacity.

increase in the total antioxidants capacity for rabbits supplemented with BP in the diet as compared to the control group. There were no significant differences in the concentrations of blood proteins, glucose, cholesterol, total lipids and TAC $(\mathrm{mm} / \mathrm{l})$ due to the interaction between rabbit line and BP treatment groups.

\section{Liver enzymes and immune responses}

From data presented in Table 5, it could be noted that the means of ALT (IU/L), IgG (mg/dl) and IgM (mg/dl) for Moshtohor bucks increased significantly $(\mathrm{P}<0.001)$ than those of $\mathrm{V}$-line. The increased immune responses could be attributed to the higher metabolic rate and the improved the immune activity in Moshtohor bucks than those in V-line.

The treated bucks with BP had significantly $(\mathrm{P} \leq 0.05)$ decreased AST and ALT than those of the control bucks. This could show that the supplementing the rabbit bucks with BP has no adverse effects on the liver 
Table 5. Liver functions, immune responses and hormonal estimates of rabbit bucks affected by rabbit line, BP treatment and their interaction between them.

\begin{tabular}{|c|c|c|c|c|c|c|c|c|c|}
\hline \multirow{2}{*}{\multicolumn{2}{|c|}{$\begin{array}{c}\text { Traits } \rightarrow \\
\text { Rabbit line } \downarrow \\
\text { Treatment } \downarrow\end{array}$}} & \multicolumn{2}{|c|}{ Liver enzymes } & \multicolumn{2}{|c|}{ Immune responses } & \multicolumn{4}{|c|}{ Hormonal estimates } \\
\hline & & $\begin{array}{c}\text { AST } \\
\text { (IU/L) }\end{array}$ & $\begin{array}{c}\text { ALT } \\
\text { (IU/L) }\end{array}$ & \begin{tabular}{|c|}
$\mathbf{I g G}$ \\
$(\mathrm{mg} / \mathrm{dl})$
\end{tabular} & $\begin{array}{c}\text { IgM } \\
(\mathbf{m g} / \mathbf{d l})\end{array}$ & \begin{tabular}{|c|} 
Testos. \\
$(\mathrm{ng} / \mathrm{ml})$
\end{tabular} & $\begin{array}{c}\text { FSH } \\
(\mathbf{n g} / \mathbf{m l})\end{array}$ & $\begin{array}{c}\mathbf{L H} \\
(\mathbf{M I U} / \mathbf{m l})\end{array}$ & $\begin{array}{c}\text { T3 } \\
\text { (ng/dl) }\end{array}$ \\
\hline \multicolumn{10}{|c|}{ Effect of rabbit line $(B)$} \\
\hline \multicolumn{2}{|c|}{ V-Line } & 28.66 & $25.71^{\mathrm{b}}$ & $58.65^{b}$ & $68.84^{\mathrm{b}}$ & 3.96 & 10.34 & 5.79 & $1.57^{\mathrm{b}}$ \\
\hline \multicolumn{2}{|c|}{ Moshtohor } & 28.95 & $26.63^{\mathrm{a}}$ & $62.99^{\mathrm{a}}$ & $74.39^{\mathrm{a}}$ & 4.27 & 10.82 & 6.06 & $1.91^{\mathrm{a}}$ \\
\hline \multicolumn{2}{|c|}{ SEM } & 0.24 & 0.21 & 1.28 & 0.96 & 0.14 & 0.32 & 0.34 & 0.03 \\
\hline \multicolumn{10}{|c|}{ Effect of BP treatment $(T)$} \\
\hline \multicolumn{2}{|c|}{ Control (C) } & $29.76^{\mathrm{a}}$ & $26.64^{\mathrm{a}}$ & $55.44^{\mathrm{b}}$ & $68.21^{b}$ & $3.55^{\mathrm{b}}$ & $9.59^{b}$ & $5.09^{b}$ & $1.40^{\mathrm{b}}$ \\
\hline \multicolumn{2}{|c|}{$250 \mathrm{mg}(\mathrm{T} 1)$} & $28.30^{\mathrm{b}}$ & $25.82^{\mathrm{b}}$ & $65.69^{\mathrm{a}}$ & $72.44^{\mathrm{a}}$ & $4.32^{\mathrm{a}}$ & $11.12^{\mathrm{a}}$ & $6.22^{\mathrm{ab}}$ & $1.88^{\mathrm{a}}$ \\
\hline \multicolumn{2}{|c|}{$500 \mathrm{mg}(\mathrm{T} 2)$} & $28.35^{\mathrm{b}}$ & $26.05^{\mathrm{ab}}$ & $63.70^{\mathrm{a}}$ & $74.19^{\mathrm{a}}$ & $4.47^{\mathrm{a}}$ & $11.04^{\mathrm{a}}$ & $6.47^{\mathrm{a}}$ & $1.95^{\mathrm{a}}$ \\
\hline \multicolumn{2}{|c|}{ SEM } & 0.29 & 0.26 & 1.57 & 1.18 & 0.17 & 0.40 & 0.41 & 0.03 \\
\hline \multicolumn{10}{|c|}{ Interaction $(B \times T)$} \\
\hline \multirow{3}{*}{ V-Line } & Control & 29.44 & 26.22 & 52.76 & 65.68 & 3.32 & 9.42 & 5.00 & 1.22 \\
\hline & $250 \mathrm{mg}$ & 28.25 & 25.34 & 58.34 & 69.59 & 4.20 & 10.84 & 6.08 & 1.70 \\
\hline & $500 \mathrm{mg}$ & 28.30 & 25.57 & 64.85 & 71.24 & 4.36 & 10.76 & 6.30 & 1.80 \\
\hline \multirow{3}{*}{$\begin{array}{l}\text { Mosh- } \\
\text { tohor }\end{array}$} & \begin{tabular}{|l|} 
Control \\
\end{tabular} & 30.09 & 27.07 & 58.12 & 70.73 & 3.78 & 9.76 & 5.18 & 1.58 \\
\hline & \begin{tabular}{|l|}
$250 \mathrm{mg}$ \\
\end{tabular} & 28.36 & 26.31 & 64.32 & 75.28 & 4.44 & 11.38 & 6.36 & 2.06 \\
\hline & $500 \mathrm{mg}$ & 28.40 & 26.53 & 66.54 & 77.15 & 4.58 & 11.32 & 6.64 & 2.09 \\
\hline \multicolumn{2}{|c|}{$\frac{1}{\text { SEM }}$} & 0.41 & 0.37 & 2.22 & 1.67 & 0.24 & 0.56 & 0.59 & 0.05 \\
\hline \multicolumn{10}{|c|}{ Probability } \\
\hline \multicolumn{2}{|c|}{ Rabbit line $(\mathrm{B})$} & 0.3996 & 0.0057 & 0.0245 & 0.0004 & 0.1243 & 0.3040 & 0.5801 & 0.0001 \\
\hline \multicolumn{2}{|c|}{ Treatment $(\mathrm{T})$} & 0.0020 & 0.0973 & 0.0005 & 0.0046 & 0.0016 & 0.0188 & 0.0617 & 0.0001 \\
\hline \multicolumn{2}{|c|}{ Interaction $(\mathrm{B} \times \mathrm{T})$} & 0.7433 & 0.9838 & 0.5860 & 0.9648 & 0.8596 & 0.9775 & 0.9901 & 0.7175 \\
\hline
\end{tabular}

$\mathrm{A}, \mathrm{b}, \mathrm{c}$ Means with different superscripts in the same column for every factor are significantly different $(\mathrm{P}<0.05)$.

AST $=$ Aspartate amino transferase, ALT $=$ Alanine amino transaminase, Testos $=$ testosterone hormone, $\mathrm{T} 3=$ Tri-iodothyronine,

tissues and their functions. These results are in agreement with those of Hedia et al., (2007), who found that the means of AST and ALT concentrations in the serum of female rabbits treated with bee pollen decreased significantly than those of the control.

It worth to mention that the levels of $\operatorname{IgG}$ and $\operatorname{IgM}$ in the treated rabbit bucks with $\mathrm{BP}$ increased significantly $(\mathrm{P}=0.01 \& 0.0373)$ than those of control. This improvement in immune responses could be attributed to the improved immune activity in the treated bucks than those of the control. These results agree with the findings of Yamada et al., (1990), who found that 
the substances known to have immunoglobulin (Ig) production stimulating factor activity as royal jelly, which increased the IgM concentration by about 2.25 -fold in the tested lymph node lymphocytes from breast cancer patients.

\section{Hormonal estimates}

Data presented in Table 5, showed that the concentration of testosterone, FSH and LH hormones in Moshtohor bucks increased insignificantly than those of V-line bucks.

The treated bucks with BP increased significantly $(\mathrm{P}=0.0016)$ the concentrations of testosterone hormone by about 17.8 and $20.6 \%$ as compared with the control group. A similar trend was obtained for FSH and LH hormones concentrations $(\mathrm{P}=0.0188$ and 0.0617 , respectively), as they increased by 13.7 and $13.1 \%$ as well as by 18.2 and $22.2 \%$ than those of the control. This improvement in testosterone, $\mathrm{FSH}$ and $\mathrm{LH}$ hormone concentrations of treated rabbit bucks may be attributed to the high contents of BP, mainly in phospholipids, vitamins, mineral and antioxidant factors (Saric'et al., 2009), which have improving effects on the fertility and semen quality traits (Xu et al., 2009 and Attia et al., 2011).

Also, the findings listed in the same table (6) indicated that the treated bucks with $\mathrm{BP}$ increased significantly $(\mathrm{P}<0.0001)$ the concentration of $\mathrm{T} 3$ (ng/dl) hormone than that of the control. This increase could reflect the better predicted metabolic functions, due to the increased T3 concentration, which antagonizes the hypothyroid state, induced by the adverse stressful effect of heat stress.

These findings agree with those of Elnagar et al., (2010), which indicated that the T3 hormone concentration in growing rabbits, orally given royal jelly once a week at 200, 400 or $800 \mathrm{mg} / \mathrm{kg}$ BW increased significantly than those of the control.

The obtained findings showed no significant differences in liver enzymes, immune responses and hormonal estimates due to the interaction between rabbit line and BP treatment.

\section{CONCLUSION}

The achieved results could be concluded as follow

1- The means of total feed intake for Moshtohor were significantly improved than those of V-line bucks, while those of BWG, FCR, and PI were insignificantly affected.

2- $\quad$ The means of glucose, total lipids, liver enzymes and T3 hormone were significantly increased than those of the V-line. 
3- $\quad$ Treating rabbit bucks with 250 and 500mg BP / buck improved FBW, BWG, and PI and reduced TFI, resulting in improving feed conversion ratio.

4- The liver enzymes, immunological responses, and physiological estimates of treated rabbit bucks were significantly improved than those of the control bucks.

Conclusively, it could be concluded that treating V-line and Moshtohor rabbits with 250 and $500 \mathrm{mg} \mathrm{BP} /$ buck, is highly recommended without any adverse effect on growing rabbits, during the summer season.

\section{ACKNOWLEDGEMENT}

This work was funded by the Agriculture Faculty, Assiut University, Assiut, Egypt.

\section{REFERENCES}

Abdel-Hamid, T.M. and Farahat, M.H. (2015). Carcass traits and some blood stress parameters of summer stressed growing male rabbits of different breeds in response to Bolden one undecylenate. J. Adv. Vet. Anim. Res., 2: 263-270.

Abou El-Naga, M. K. (2014). Effect of bee pollen supplementation on productive and reproductive performance of norfa chicken. Egypt. Poult. Sci., 34: 119-132.

Almaraz-Abarca, N.; Campos, M.G.; Avila-Reyes, J.A.; Naranjo-Jimenez, N.; Herrera-Corral, J. and Gonzalez-Valdez, L.S. (2004). Variability of antioxidant activity among honeybee-collected pollen of different botanical origin, Interciencia, 29: 574-578.

A.O.A.C (1990). Official Methods of Analysis. Association of Official Analytical Chemist. $15^{\text {th }}$ Edition Assoc. Of Analytic Chemists, Arlington, VA.

Armstrong, W.D. and Corri C.W. (1960). Physiological chemistry. Laboratory Diction, $3^{\text {rd }}$ Edition, P 75 Plunges Publishing Co., Minneapolis, USA.

Attia, Y.A.; Al-Hanoun, A. and Bovera, F. (2011a). Effect of different levels of bee pollen on performance and blood profile of New Zealand White bucks and growth performance of their offspring during summer and winter months. Journal of Animal Physiology and Animal Nutrition, 95: $17-26$. 
Attia, Y.A.; AL-Hanoun, A.; EL-Din, A.E.; Bovera, F. and Shewika, Y.E. (2011b). Effect of bee pollen levels on productive, reproductive and blood traits of NZW rabbits. Journal of Animal Physiology and Animal Nutrition, 95: 294-303.

Attia, Y.A; El-Hanoun, A.M.; Bovera, F.; Monastra, G.; El-Tahawy, W. S. and Habiba H.I. (2014). Growth performance, carcass quality, biochemical and hematological traits and immune response of growing rabbits as affected by different growth promoters. Journal of Animal Physiol. Anim. Nutr., 98: 128-139.

Bastos, D.H.M. (2004). Fatty acid composition and palynological analysis of bee (Apis) pollen loads in the states of Sao Paulo and Minas Gerais, Brazil, Journal of Apicultural Research, 43: 35-39

Campos, M.G.R.; Frigerio, C.; Lopes, J. and Bogdanov S. (2010). What is the future of Bee-Pollen?. Journal of Applied Product. and Applied Medical Sci., 2: 131-144.

Carpes, S.T., Begnini, R. and De Alencar, S.M. (2007). Study of preparations of bee pollen extracts, antioxidant and antibacterial activity. Ciênc. Agrotec. Lavras, 31:1818-1825.

Carpes, S. T.; Prado, A.; Moreno, I. A. M.; Mourão, G. B.; Alencar, S. M. and Masson, M.L. (2008). Avaliação do potencial antioxidante do pollen apícolaproduzido na região sul do Brasil. Química Nova., 31: 660-1664.

Dias, D. M. B.; Maria C. O.; Diones M. S.; Nadielli P. B.; Daniel C. C. And A. M., Wilson (2013). Bee pollen supplementation in diets for rabbit does and growing rabbits. Acta Scientiarum Animal Sciences,35: 425-430.

Doumas, B.; Wtson, W. and Biggs, H. (1971). Albumin standers measurements of serum with bromocresol green. Clinical Chemistry Acta., 31-37.

Drew, P., Harles, C. R. J. S., Trevor, B. and John, L. (2004). Oxford Handbook of Clinical Haematology. 2th Edition, Oxford University Press, USA.

Duncan, D. B. (1955).Multiple Range and Multiple F. Test. Biometrics,11: 1-42.

El-Bayomi, Kh. M.; El-Tarabany, M. S. and Abdel-Hamid, T. M. (2012). Estimation of heterosis and combining ability for some weaning and post-weaning traits in three different breeds of rabbits. Journal of American Science, 8: 282-288.

El-Hanoun, A. M.; Kamel, K.I.; El- Sebaei, M.S.; Gad, H. A. M. (2007). Effect of Egyptian propolis supplementation on productive, reproductive performance and some hematobiochemical parameters and steroid hormones of female rabbits during winter and summer seasons. In Proc.:4th World Poultry Conference, 27-30 March, 2007. Sharm ElSheikh, Egypt. 417-423. 
El- Nagar, S. A.; El- ghalid, O. A. and Abd-El- hady, A. M. (2010). Royal jelly: can it reduce physiological strain of growing rabbits under Egyptian summer conditions? Animal, 4(9): 1547-1552.

El-Neney, B. A. M. and El-Kholy, K. H. (2014). Effect of natural additive (bee pollen) on immunity and productive and reproductive performances in rabbits. 1-Growth performance, digestive and immune responses in growing rabbits. Egypt. Poult. Sci.,34: 579-606.

Erel, O. (2004). A novel automated method to measure total antioxidant response against potent free radical reactions. Clin. Biochem., 37: 112119. doi: 10.1016/j. clinbiochem. 2003.10.014

Estany, J.; Baselga, M.; Blasco, A. and Camacho, J. (1989). Mixed model methodology for the estimation of genetic response to selection in litter size of rabbits. Livestock. Prod. Sci., 21:67-76.

García, M.; Pérez-Arquillue, C.; Juan, T.; Juan, M.I. and Herrera, A. (2001). Note: pollen analysis and antibacterial activity of Spanish honeys. Int. J. Food Sci. Technol., 7: 155-158.

Hajkova, Z.; Toman, R.; Huchý, S.; Gálik, B.; Bíro, D.; Martiniaková, M.; Omelka, R. and Boboňová, I. (2013). The effect of pollen on the structure of the small intestine in rats after an experimental addition in diet. Anim. Sci. and Bio., 46: 232-237.

Haščík, P.; Elimam, I. O. and Garlík, J. (2012). The effect of addition bee pollen to feed mixtures on internal fat of broiler Ross 308. JMBFS., 2: 246-252.

Hedia, H. A.; Kamel, I. K.; El-Sbeiy, M. S. and El- Hanoun, A. M. (2007). Effect of Egyptian bee pollen supplementation on some reproductive performance and hematobiological constituents of female rabbits during winter and summer seasons. $4^{\text {th }}$ World Poult. Conf., 27-30 March, Sharm El-Sheik, 579-594.

Human, H. and Nicolson, S.W. (2003). Digestion of maize and sunflower pollen by the spotted maize beetle Astylus atromaculatus (Melyridae): Is there a role for osmotic shock, Journal of Insect Physiology., 49: 633-643.

Iraqi, M.M.; Afifi, E.A.; Baselga, M.; Khalil, M. H. and García, M. L. (2008). Additive and heterotic components for post-weaning growth traits in a crossing project of V-line with Gabali rabbits in Egypt. In Proc. 9th World Rabbit Congress, Verona, Italy., 131-136.

Khalil, H.A.; Yaseen, M.A. and Hamdy, A. M. M. (2015). Behavioral Activities, Physiological Body Reactions, HematologicalParameters and Hormonal Profiles for Bucks of New Zealand Whiteand Baladi Red Rabbits Exposed to Short Term of High Temperature. Asian Journal of Poultry Science, 9: 191-202. 
Leblanc, B.W.; Davis, O.K.; Boue, S.; DeLuca, A. and Deeby, T. (2009). Antioxidant activity of Sonoran Desert bee pollen, Food Chem., 115: 1299-1305.

Marai, I.F.M.; Ayyat, M.S. and Abdel-Monem, U.M. (2001). Growth performance and reproductive traits at first parity of New Zealand White female rabbits as affected by heat stress and its alleviation, under Egyptian conditions. Tropical Anim. Health and Prod., 33: 451-462.

North, O.M. (1981).Commercial production Manual. 2nd ED., AVI publishing company, Inc. Westport, Connecticut.

Ondruska, L. J.; Rafay, A.B.; Okab, M.A.; Ayoub, A.A.; Al-Haidary, E.M.; Samara, V.; Parkanyi, L.; Chrastinova, R.; Jurcik, P.; Massanyi, N.L. and Supuka, P. (2011). Influence of elevated ambient temperature upon some physiological measurements of New Zealand White rabbits. Veterinaria Medicina., 56: 180-186.

Perić, L.; Ţikić, D. and Lukić, M. (2009). Application of alternative growth promoters in broiler production. Biotechnology in Animal Husbandry, 25: 387-397.

Proestos, C.; Chorianopoulos, N.; Nichas, G. J. E. and Komaitis, M. (2005). RP-HPLC analysis of the phenolic compounds of plant extracts: investigation of their antioxidant capacity and antimicrobial activity. Journal Agricultural Food Chemistry, 53:1190-1195.

Reitman, S. and Frankle S. (1957). Glutamic oxaloacetic transaminase colorimetric method. Amer, J. Clin. Path., 28: 56.

Saric, A.; Balog, T.; Sobocanec, S.; Kusic, B.; Sverko, V.; Rusak, G.; Likic, S.; Bubalo, D.; Pinto, B.; Reali, D. and Marotti, T. (2009). Antioxidant effects of flavonoid from Croatian Cystus incanus L. rich bee pollen. Food and Chemical Toxicology, 47: 547-554.

SAS. Statistical Analysis Systems Institute. (2004). SAS/STAT user's guide: release 6.03. SAS institute Inc., Cary, NC. USA.

Song, Y.; Wang, J.; Sheng, L. and Shang, C. (2005). Effect of bee pollen on the development of digestive gland of broilers, China Animal Husbandry and Veterinary Medicine., 37: 14-17.

Tietz, N.W. (1995). Clinical Guide to Laboratory Tests. Third Edition, pp. 578-580, W.B. Saunders Company, Philadelphia.

Villanueva, M.T.O. (2002). The importance of bee collected pollen in the diet: a study of its composition. International Journal of Food Sciences and Nutrition.53: 217-224.

Xu, X.; Sun, L.; Dong, J. and Zhang, H. (2009). Breaking the cells of rape bee pollen and consecutive extraction of functional oil with supercritical carbon oxide. Innovative Food Sci. and Emerging Tech., 10: 42-46. 
Yamada K., Ikeda I., Maeda M., Shirahata S. and Murakami H. (1990). Effect of immunoglobulin production stimulating factors in foodstuffs on immunoglobulin production of human lymphocytes. Agri. Biol. Chem. Tokyo, 54: 1087-1089. doi:10.1271/bbb1961.54.1087

\section{الاداء الإنتاجي، مكونات الام و بعض المقاييس الفسيولوجية لأكور

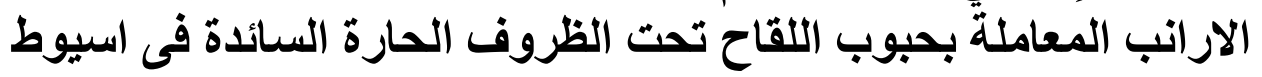 \\ أحمد عبدالكريم ابوغابة1، حاتم يوسف الحمادي²، مصطفى جلال عبدالفتاح2

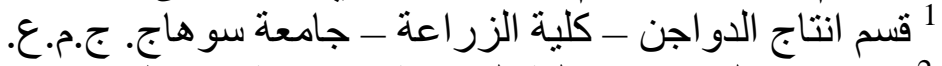

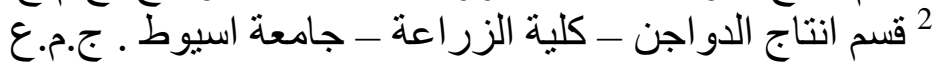

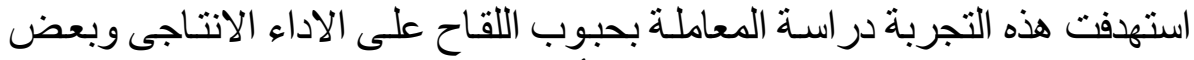

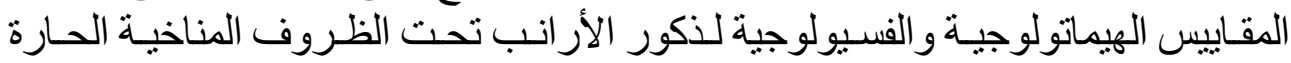
السائدة في اسيوط خلائل فصل الصيف.

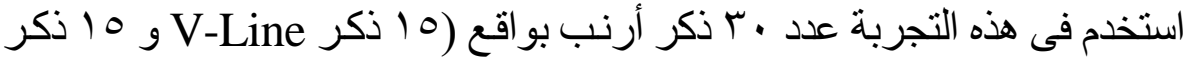

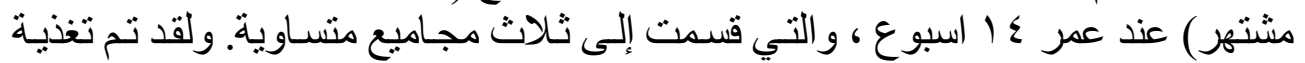

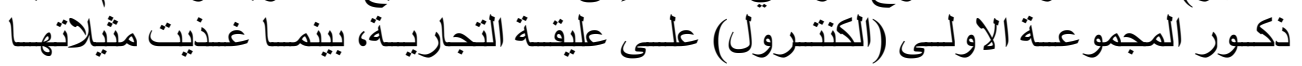

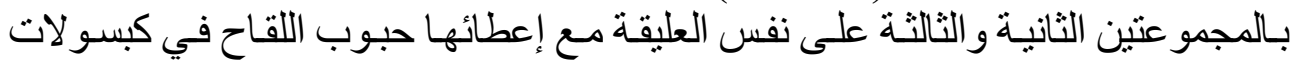

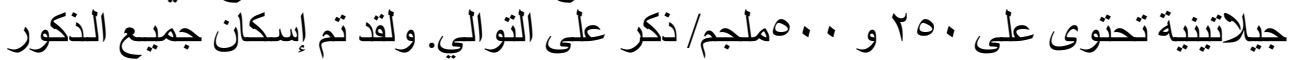

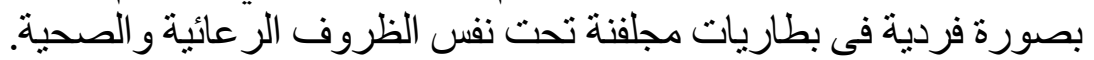

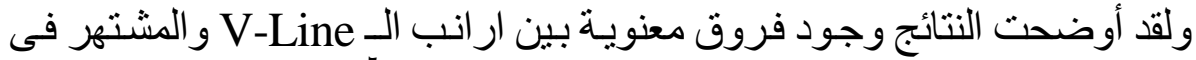

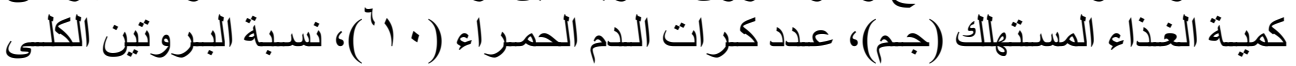

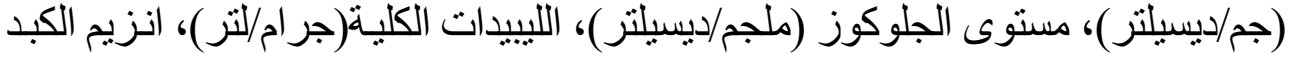
ALT (يودوثيرونين(نانوجر ام/ديسيلتر ). هذا ولم توجد فروق معنوية بين ار انب الـ لـ-Line و المشتهر فئ صفات الاداء

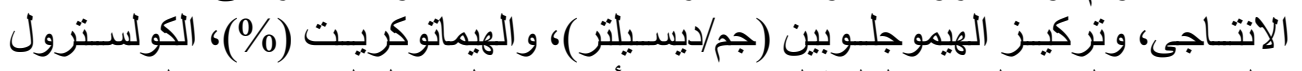

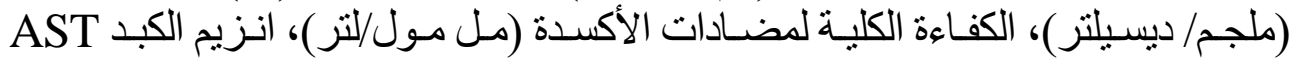

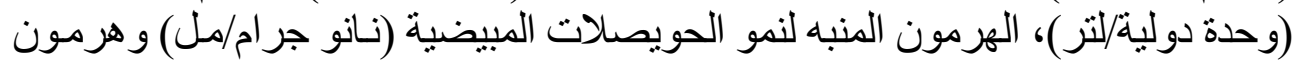

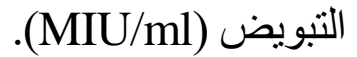

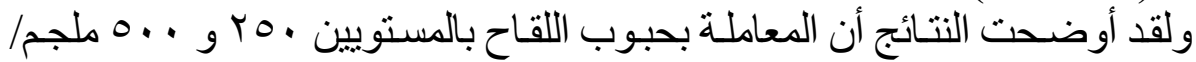

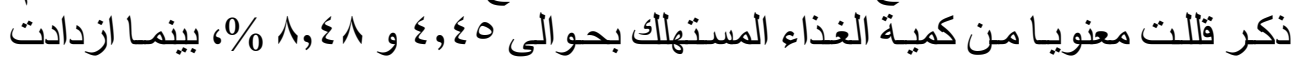


معنويـاً منوسطات وزن الجسم (جم)، ومعدل الزيـادة اليوميـة (جم) ومعدل النمو (\%)

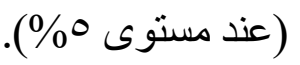

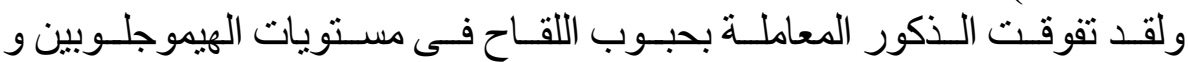
الهيماتوكريت وعدد كرات الدم الحمر اءو والخلايـا الليمفاوية (\%) بالمقارنة بمثنيلاتها في

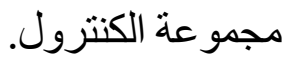

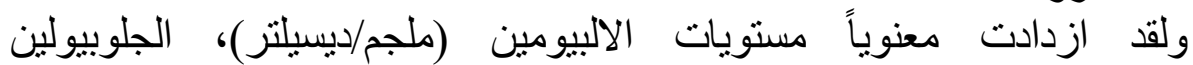
(ملجم/ديسيلتر) و الجلوكوز (ملجم/ديسيلتر) بالإضافة إلى الكفاءة الكياء الكلية لمضادادات

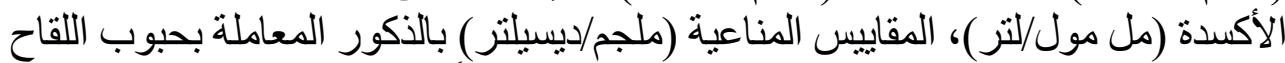

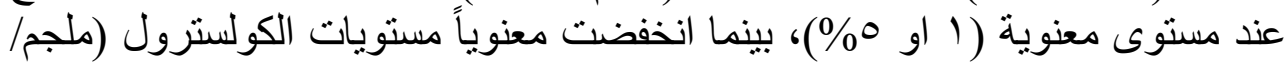

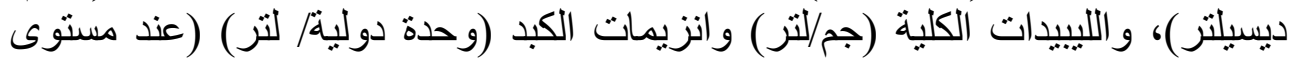

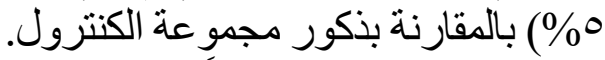

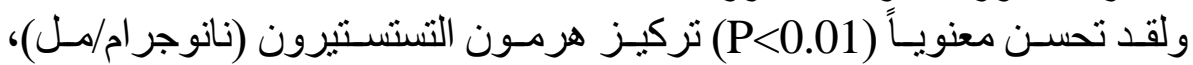

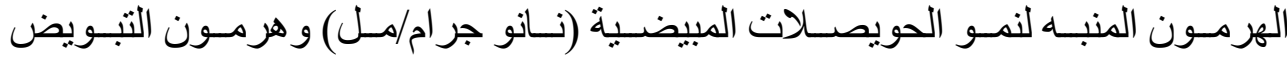
(MIU/ml)

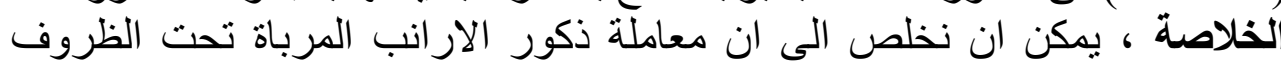

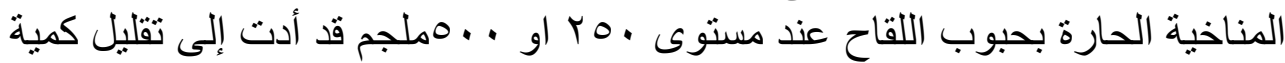

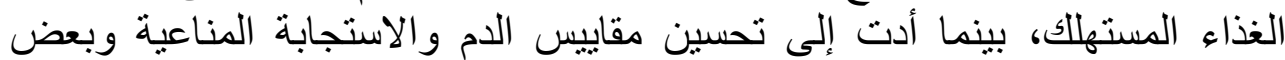

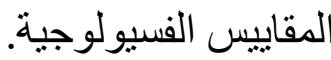
مفاتيح البحث: حبوب اللقاح ، ذكور الأرانب، الأداء الإنتاجي، الاستجابة المناعية ،

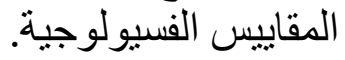

